\title{
Histone deacetylase inhibitors induce cell death and enhance the susceptibility to ionizing radiation, etoposide, and TRAIL in medulloblastoma cells
}

\author{
JÜRGEN SONNEMANN ${ }^{1}$, K. SARAVANA KUMAR ${ }^{1}$, SANDRA HEESCH ${ }^{1}$, CORNELIA MÜLLER ${ }^{2}$, \\ CHRISTOPH HARTWIG ${ }^{3}$, MANFRED MAASS $^{3}$, PETER BADER ${ }^{4}$ and JAMES F. BECK ${ }^{2}$ \\ ${ }^{1}$ Peter Holtz Research Center of Pharmacology and Experimental Therapeutics, \\ Departments of ${ }^{2}$ Pediatric Oncology/Hematology and ${ }^{3}$ Radiotherapy, Ernst Moritz Arndt University, \\ Greifswald; ${ }^{4}$ Department of Pediatric Hematology/Oncology, University of Tübingen, Germany
}

Received September 23, 2005; Accepted November 16, 2005

\begin{abstract}
Histone deacetylase inhibitors (HDIs) are a promising new class of antineoplastic agents with the ability to induce apoptosis and growth arrest of cancer cells. In addition, HDIs have been suggested to enhance the anticancer efficacy of other therapeutic regimens, such as ionizing radiation (IR) or chemotherapy. The objective of this study was to evaluate the activity of HDIs against medulloblastoma cells when applied either as single agents or in combination with IR, cytostatics, or TRAIL. The HDIs, suberoyl anilide hydroxamic acid (SAHA), sodium butyrate, and trichostatin A, were examined for their effects on the medulloblastoma cell lines, DAOY and UW228-2. We found that treatment with HDIs induced the dissipation of mitochondrial membrane potential, activation of caspase- 9 and -3 and, consequently, apoptotic cell death. Moreover, all three HDIs significantly enhanced the cytotoxic effects of IR in DAOY cells. Likewise, treatment with SAHA markedly augmented the cytotoxicity of etoposide, while it had no effect on vincristine-mediated cell death. HDIs also potently increased the killing efficiency of TRAIL. TRAIL-induced, but not SAHA-induced, cell killing could be prevented by the caspase- 8 inhibitor, z-IEDT-fmk. We conclude that HDIs may be useful for the treatment of medulloblastoma as monotherapy and particularly when given in combination with IR, appropriate cytostatics, or TRAIL.
\end{abstract}

\section{Introduction}

Medulloblastoma is the most common brain tumor of childhood. It is a highly malignant neoplasia and, despite

Correspondence to: Dr James F. Beck, Zentrum für Kinder- und Jugendmedizin, Abteilung für Pädiatrische Onkologie und Hämatologie, Soldmannstrasse 15, D-17487 Greifswald, Germany

E-mail: beck@uni-greifswald.de

Key words: etoposide, histone deacetylase inhibitors, medulloblastoma, radiotherapy, TRAIL aggressive multimodality treatment with surgery, ionizing radiation (IR), and chemotherapy, more than a third of children with medulloblastoma die from the disease within 5 years of diagnosis (1). Moreover, survivors of medulloblastoma commonly have severe treatment-induced neurocognitive sequelae (2). Hence, more effective treatment strategies aimed both at improving the chance of survival and at reducing therapy-related long-term side-effects are urgently needed for this disease.

Currently, considerable attention focuses on histone deacetylase inhibitors (HDIs) as antineoplastic agents. HDIs are a novel class of relatively specific anticancer drugs which were originally identified by their capacity to reverse the transformed phenotype (3). Subsequently, they have been shown to prevent proliferation, activate differentiation, and/or induce apoptosis of tumor cells. HDIs function by inhibiting histone deacetylases, resulting in the accumulation of acetylated histones, in turn leading to an increase in transcriptionally active chromatin (4). In so doing, they reactivate the gene expression of dormant tumor suppressor genes, such as CDKN1A (p21) (5). However, in spite of the growing interest in these agents, the molecular basis underlying their anticancer action is not fully understood.

Recently, HDIs have been introduced as chemotherapeutic compounds. As such, their antitumor activity was observed in cell lines originating from different types of human cancer, including neuroblastoma (6), breast cancer (7), prostate cancer (8), and renal cancer (9). In addition, studies on mice xenograft models of human neoplasia have demonstrated anticancer effects of HDIs on colorectal, lung, pancreatic and ovarian cancer (10) as well as prostate cancer (8). Most notably, they have been shown both in vitro and in vivo to affect cancer cells while leaving normal cells comparatively unscathed $(8,11)$. The clinical potential of these agents has been documented by several Phase I trials of different HDIs in patients with solid tumors or leukemias (12-17). Various HDIs have been evaluated in brain tumors in a few studies (18-22) but, with the exception of MS-275 (23) and phenylbutyrate and phenylacetate (24), not in pediatric medulloblastoma.

In the present study, we assessed the effects of three different HDIs belonging to two structural classes, the hydroxamic acids, suberoylanilide hydroxamic acid (SAHA) and 
trichostatin A (TSA), and the carboxylic acid, sodium butyrate $(\mathrm{NaB})$, in the medulloblastoma cell lines, DAOY and UW228-2. Our results show that all three compounds elicit cell death in both cell lines. Even more importantly, we demonstrate that HDIs are capable of enhancing the cytotoxic activity of IR, etoposide, or TRAIL (tumor necrosis factor-related apoptosis-inducing ligand) in medulloblastoma cells.

\section{Materials and methods}

Reagents. SAHA, TSA, and the pan-caspase inhibitor, z-VADfmk, were purchased from Alexis (Grünberg, Germany). $\mathrm{NaB}$, etoposide, and vincristine were purchased from Sigma (Deisenhofen, Germany). TRAIL was purchased from Peprotech (Rocky Hill, NJ, USA). The caspase-8 inhibitor, z-IETDfmk, was purchased from Merck Biosciences (Schwalbach, Germany).

Cell culture. DAOY and UW228-2 medulloblastoma cells were a gift from Dr M. Grotzer (Zurich, Switzerland) and were maintained in Improved MEM Zinc Option (Invitrogen, Karlsruhe, Germany) or DMEM medium, respectively, supplemented with $10 \%$ fetal calf serum, $2 \mathrm{mM}$ L-glutamine, 100 units $/ \mathrm{ml}$ penicillin $\mathrm{G}$ sodium, and $100 \mu \mathrm{g} / \mathrm{ml}$ streptomycin sulfate (DMEM and supplements were purchased from Biochrom, Berlin, Germany). Cells were cultivated at $37^{\circ} \mathrm{C}$ in a humidified $5 \% \mathrm{CO}_{2}$ incubator and routinely passaged when $90-95 \%$ confluent. Cell viability was determined by the trypan blue exclusion test. Cells were regularly inspected to be free of mycoplasma with mycoplasma detection reagents from Roche (Mannheim, Germany). To inhibit the activation of caspases, $\mathrm{z}-\mathrm{VAD}$-fmk was applied $1 \mathrm{~h}$ before treatment with HDIs.

Ionizing radiation. Cells were exposed to IR using a Siemens Mevatron MXE linear accelerator (Siemens, Concord, CA, USA) delivering photon beams of $6 \mathrm{MV}$.

Cytofluorometric analysis of cell death. To determine cell death, cells were harvested after 24- to 72-h cultivation in the presence of HDIs, followed by a 5 -min incubation in $2 \mu \mathrm{g} / \mathrm{ml}$ propidium iodide (PI) (Sigma) in $\mathrm{PBS}$ at $4^{\circ} \mathrm{C}$ in the dark. PI uptake was assessed by flow cytometry analysis on a Becton Dickinson (Heidelberg, Germany) FACScalibur using CellQuest software. In each sample, 10,000 cells were analyzed; data were gated to exclude debris.

Cytofluorometric analysis of DNA content. To measure the DNA content, cells were analyzed for PI incorporation into DNA. Cells were harvested 24-72 h after treatment with HDIs, washed twice with PBS and fixed in $70 \%$ ethanol at $-20^{\circ} \mathrm{C}$ for at least $30 \mathrm{~min}$. After centrifugation, cells were resuspended in PBS containing $1 \%$ glucose, $50 \mu \mathrm{g} / \mathrm{ml} \mathrm{RNase} \mathrm{A}$ (Roche) and $50 \mu \mathrm{g} / \mathrm{ml} \mathrm{PI}$ and incubated in the dark at room temperature for $30 \mathrm{~min}$. Flow cytometry analysis was performed on a FACScalibur using CellQuest software. In each sample, 20,000 cells were analyzed; data were gated to exclude debris. Sub- $\mathrm{G}_{1}, \mathrm{G}_{1}$ and $\mathrm{G}_{2} / \mathrm{M}$ phase cells were calculated from the DNA content histograms.
Cytofluorometric analysis of mitochondrial transmembrane potential $\left(\Delta \Psi_{m}\right) . \Delta \Psi_{\mathrm{m}}$ was determined by assessing the accumulation of the cationic lipophilic fluorochrome, 3,3'dihexyloxacarbocyanine iodide $\left[\operatorname{DiOC}_{6}(3)\right]$, in the mitochondrial matrix. Twenty-four hours after treatment with HDIs, cells were incubated with $50 \mathrm{nM} \mathrm{DiOC}_{6}(3)$ (Molecular Probes, Eugene, OR, USA) at $37^{\circ} \mathrm{C}$ for $30 \mathrm{~min}$. After washing, 10,000 cells were analyzed using a FACScalibur and CellQuest software. Data were gated to exclude debris.

Caspase- 3 and -9 activity. Caspase activity was measured $24 \mathrm{~h}$ after treatment with HDIs using the synthetic fluorogenic substrates, Ac-DEVD-AFC or Ac-LEHD-AFC (Bachem, Heidelberg, Germany), for determining caspase-3 and -9 activity, respectively. Cells were lysed in $10 \mathrm{mM}$ Tris- $\mathrm{HCl}$, $10 \mathrm{mM} \mathrm{NaH}{ }_{2} \mathrm{PO}_{4} / \mathrm{NaHPO}_{4}(\mathrm{pH} 7.5), 130 \mathrm{mM} \mathrm{NaCl}, 1 \%$ Triton-X-100, and $10 \mathrm{mM} \mathrm{Na} \mathrm{P}_{2} \mathrm{O}_{7}$ and then incubated with $20 \mathrm{mM}$ HEPES (pH 7.5), 10\% glycerol, 2 mM DTT and $25 \mu \mathrm{g} / \mathrm{ml} \mathrm{Ac-DEVD-AFC}$ or $25 \mu \mathrm{g} / \mathrm{ml}$ Ac-LEHD-AFC at $37^{\circ} \mathrm{C}$ for $2 \mathrm{~h}$. The release of trifluoromethylcoumarin (AFC) was analyzed on a Wallac Victor fluorometer (Perkin-Elmer, Rodgau-Jügesheim, Germany) using an excitation/emission wavelength of $390 / 510 \mathrm{~nm}$. Relative caspase activity was calculated as a ratio of emission of treated cells to untreated cells.

Western blot analysis. Cells were lysed on ice for $15 \mathrm{~min}$ in $40 \mathrm{mM}$ Tris- $\mathrm{HCl}$ (pH 7.4), $150 \mathrm{mM} \mathrm{NaCl}, 1 \%$ Triton $\mathrm{X}-100$, $0.5 \%$ sodium deoxycholate, and $0.1 \%$ SDS supplemented with a protease inhibitor cocktail (Roche) followed by brief sonification. Protein concentration was assayed using bicinchoninic acid (Pierce, Rockford, IL, USA) according to the manufacturer's instructions. For immunoblotting, $30 \mu \mathrm{g}$ of total cellular protein per lane was separated by standard SDS-PAGE on $10 \%$ gels and electrophoretically transferred to PVDF membranes (Millipore, Eschborn, Germany). After blocking in PBS containing 5\% dry milk and $0.05 \%$ Tween-20, acetylated histone $\mathrm{H} 3$ was immunodetected using rabbit antiacetylated histone $\mathrm{H} 3$ polyclonal antibody (dilution 1:40,000; Upstate Biotechnology, Lake Placid, NY, USA). Even loading of protein was verified by detection of GAPDH using mouse anti-GAPDH monoclonal antibody (dilution 1:10,000; BioDesign International, Saco, ME, USA). Peroxidase-conjugated goat anti-rabbit or anti-mouse IgGs (dilution 1:25,000; Dianova, Hamburg, Germany) followed by enhanced chemiluminescence (Amersham Biosciences, Freiburg, Germany) were used for detection.

Statistical analysis. Statistical significance of differences between experimental groups was determined using the paired two-tailed Student's t-test.

\section{Results}

HDIs induce cell death in medulloblastoma cells. To investigate possible cytotoxic effects of HDIs on medulloblastoma cells, we initially monitored cell killing by assessing the integrity of the cell membrane by cytofluorometric analysis of PI uptake. DAOY and UW228-2 cells were cultured without or with SAHA (2-20 $\mu \mathrm{M}), \mathrm{NaB}(1-10 \mathrm{mM})$, or TSA $(0.2-2 \mu \mathrm{M})$ for 
A

SAHA
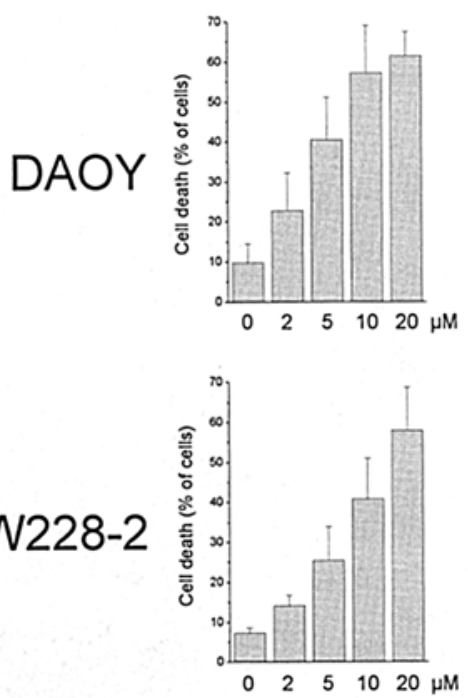

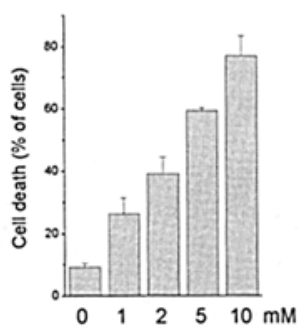

$\mathrm{NaB}$

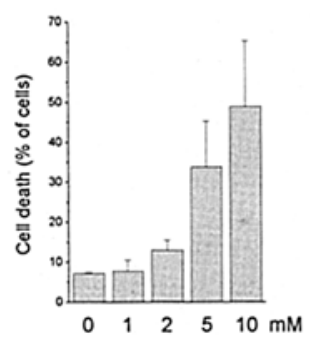

TSA
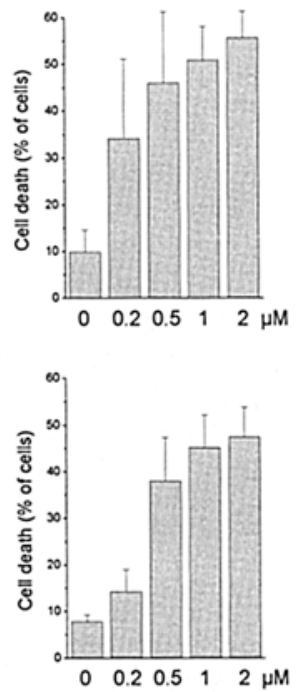

$+z-V A D-f m k$
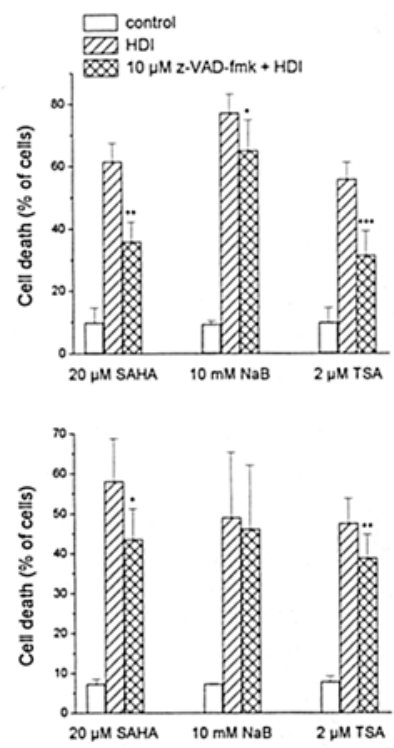

Figure 1. HDIs induce cell death. (A) DAOY cells were incubated with SAHA and TSA for $24 \mathrm{~h}$, and with NaB for 48 h; UW228-2 cells were incubated with SAHA and TSA for $48 \mathrm{~h}$, and with NaB for $72 \mathrm{~h}$. (B) z-VAD-fmk was applied $1 \mathrm{~h}$ before treatment with HDIs, cells were then incubated for 24-72 h. Cell death was determined by cytofluorometric analysis of PI uptake. Means \pm SD of 4 separate experiments are shown $\left({ }^{*} \mathrm{p}<0.05,{ }^{* *} \mathrm{p}<0.005,{ }^{* * *} \mathrm{p}<0.001\right)$.

24-72 h (DAOY: SAHA and TSA, 24 h; NaB, 48 h; UW2282: SAHA and TSA, 48 h; NaB, 72 h). For both cell lines, we observed a concentration-dependent increase in dead cells with increasing doses of the three compounds (Fig. 1A). After treatment with $20 \mu \mathrm{M}$ SAHA, approximately $60 \%$ of DAOY or UW228-2 cells were non-viable; similar results were obtained with $10 \mathrm{mM} \mathrm{NaB}$ and $2 \mu \mathrm{M}$ TSA.

\section{HDI-induced cell death in medulloblastoma cells involves apoptosis}

$z-V A D-f m k$. Subsequently, we explored whether SAHA-, $\mathrm{NaB}-$, and TSA-induced cell death in DAOY and UW228-2 cells could be induced by apoptosis. Apoptosis was evaluated by using the broad-spectrum irreversible caspase inhibitor, z-VAD-fmk, by assessing DNA fragmentation with cytofluorometric cell cycle analysis and by measuring caspase- 3 activity. First, the effect of z-VAD-fmk on HDI-mediated cell death was examined by determining PI uptake. z-VAD-fmk $(10 \mu \mathrm{M})$ was applied $1 \mathrm{~h}$ before administration of SAHA, $\mathrm{NaB}$, or TSA, and cells were cultured for 24-72 h. In DAOY cells, the pan-caspase inhibitor significantly, albeit partially, prevented HDI-induced cell killing (Fig. 1B). In contrast, only a tenuous protective effect of $\mathrm{z}$-VAD-fmk was observed in UW228-2 cells.

DNA fragmentation. Second, cells were assessed for apoptosis by cell-cycle analysis: the sub- $\mathrm{G}_{1}$ (hypodiploid) subpopulation of cells is indicative of apoptosis. As shown in Fig. 2A, there was a concentration-dependent increase in sub- $\mathrm{G}_{1}$ cells, consistent with DNA fragmentation and apoptosis, with increasing doses of SAHA, NaB, or TSA in both DAOY and UW228-2 cells. The control (no HDIs) samples showed sub- $\mathrm{G}_{1}$ fractions of approximately 5\%, whereas samples cultured with HDIs for $24 \mathrm{~h}$ showed sub- $\mathrm{G}_{1}$ fractions of $32-43 \%$ (DAOY) or $12-20 \%$ (UW228-2), concomitant with reduced $\mathrm{G}_{1}$ fractions. In DAOY cells, pretreatment with $10 \mu \mathrm{M}$ z-VAD-fmk significantly antagonized HDI-induced DNA fragmentation, while no protection of $\mathrm{z}-\mathrm{VAD}$-fmk against HDI-induced DNA fragmentation was detected in UW228-2 cells (Fig. 2B). Interestingly, with the inhibition of caspases, a significant $\mathrm{G}_{2} / \mathrm{M}$ arrest, largely concealed after exposure to HDIs alone, became evident in DAOY cells.

Caspase-3. The activation of caspase- 3 is a hallmark of apoptosis in many cell types (25). Thus, we assessed whether HDIs would induce caspase- 3 activity in DAOY and UW228-2 cells. As illustrated in Fig. 3, a 24-h incubation with SAHA, $\mathrm{NaB}$, or TSA triggered caspase- 3 activity in a dose-dependent manner in both cell lines. In DAOY cells, HDIs provoked an up to 18 -fold increase in caspase-3 activity; in UW228-2 cells, an up to 5.5-fold increase in caspase- 3 activity was observed.

HDIs induce the mitochondrial pathway of apoptosis in medulloblastoma cells. Mitochondrial transmembrane potential $\left(\Delta \Psi_{\mathrm{m}}\right)$. HDIs have been reported to harness the mitochondrial pathway of apoptosis in different cancer types (26-28). To evaluate whether HDI-induced apoptosis would involve mitochondria in medulloblastoma cells, we examined mitochondrial depolarization by determining $\Delta \Psi_{\mathrm{m}}$ and measured caspase-9 activity. A concentration-dependent decline of $\Delta \Psi_{\mathrm{m}}$ was found for all the three HDIs in both cell lines (Fig. 4A). A 24-h treatment with HDIs caused a $\Delta \Psi_{\mathrm{m}}$ dissipation in $30-46 \%$ of DAOY cells and $12-25 \%$ in UW228-2 cells. In DAOY cells, the decay of $\Delta \Psi_{\mathrm{m}}$ was significantly inhibited by preincubation with $10 \mu \mathrm{M} \mathrm{z}$-VAD-fmk (Fig. 4B). In contrast, z-VAD-fmk did not inhibit HDI-triggered loss of $\Delta \Psi_{m}$ in UW228-2 cells. 


\section{DAOY}
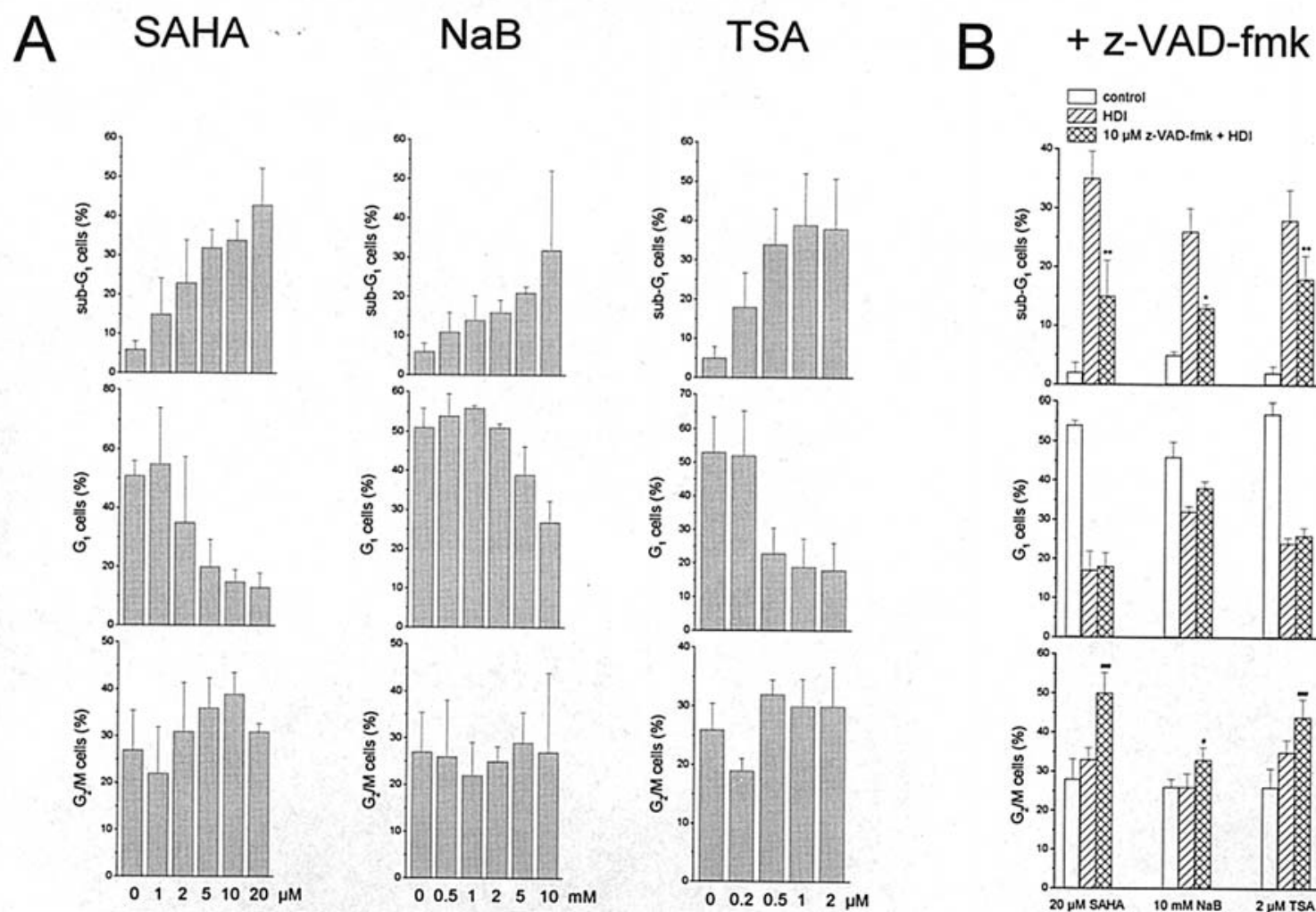

UW228-2

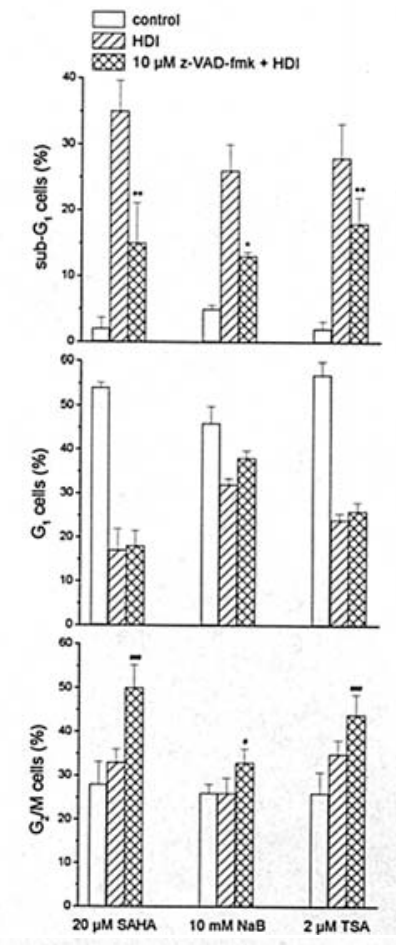

A SAHA
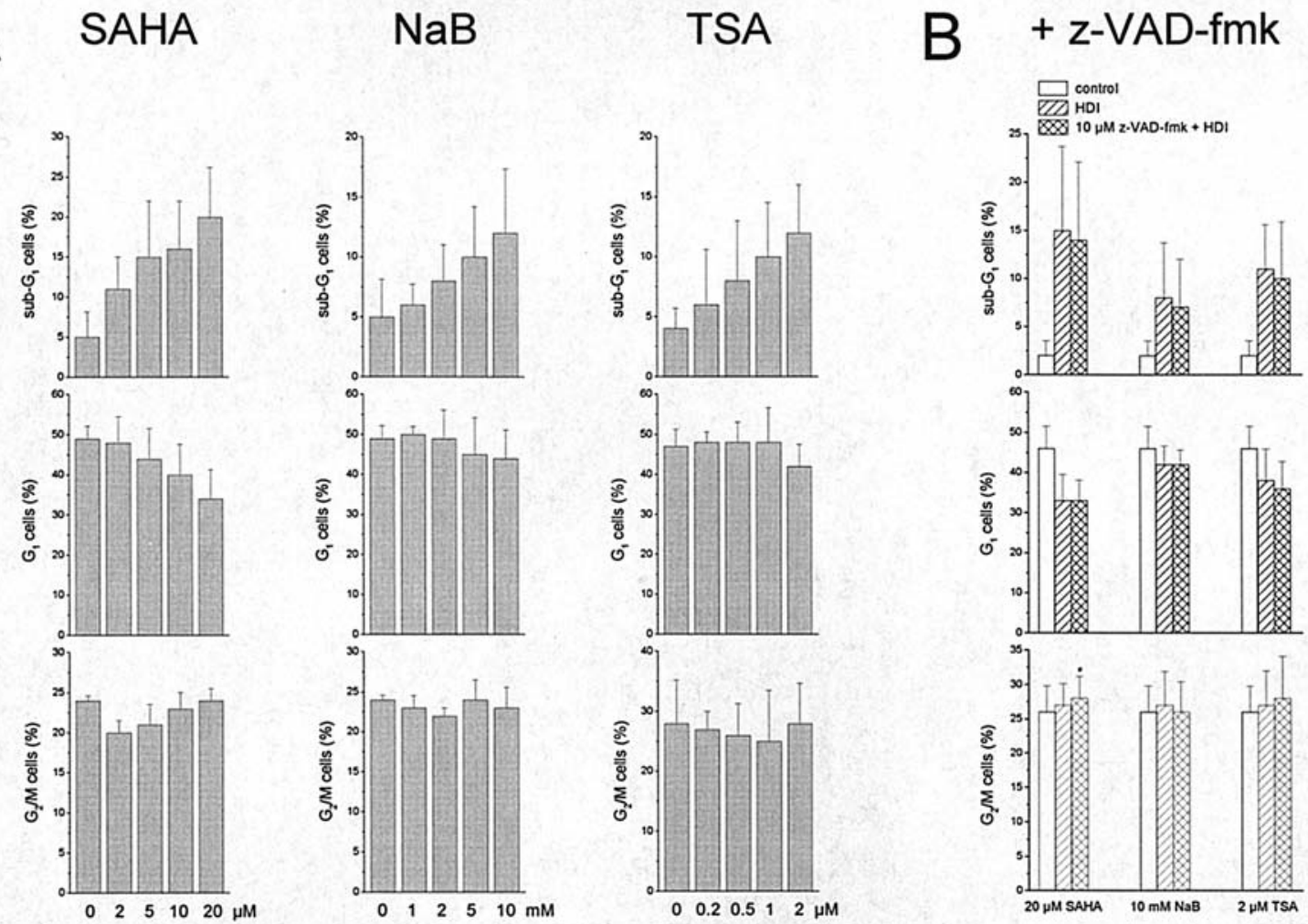

Figure 2. HDIs alter cell-cycle profile. (A) DAOY and UW228-2 cells were incubated with SAHA, NaB, or TSA for $24 \mathrm{~h}$. (B) z-VAD-fmk was applied $1 \mathrm{~h}$ before treatment with HDIs, cells were then incubated for $24 \mathrm{~h}$. Cell cycle profiles were analyzed by flow cytometry. Means \pm SD of 3 separate experiments are shown (z-VAD-fmk versus HDI: ${ }^{*} \mathrm{p}<0.05,{ }^{* *} \mathrm{p}<0.005$; $\mathrm{z}-\mathrm{VAD}-\mathrm{fmk}$ versus control: $\left.{ }^{\#} \mathrm{p}<0.05,{ }^{\# \# \#} \mathrm{p}<0.001\right)$. 
SAHA
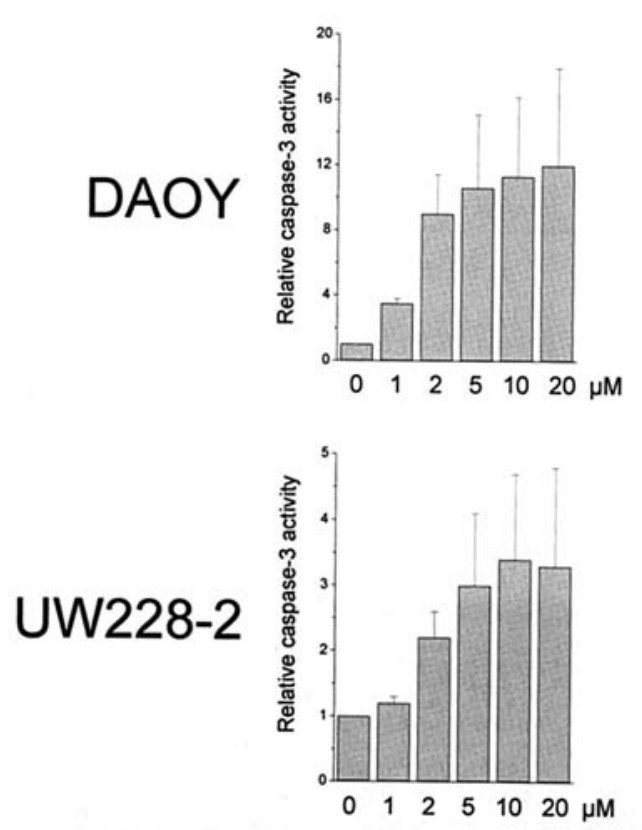

$\mathrm{NaB}$
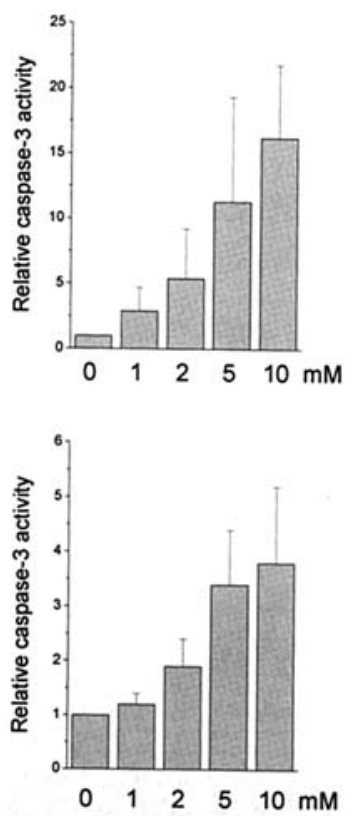

TSA
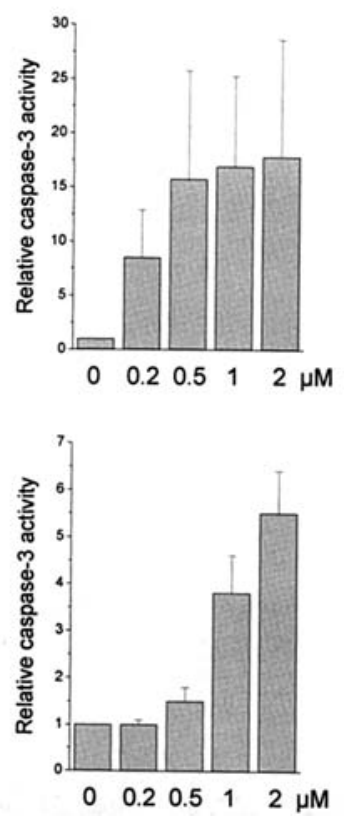

Figure 3. HDIs induce caspase-3 activity. DAOY and UW228-2 cells were incubated with SAHA, NaB, or TSA for 24 h. Caspase-3 activity was measured using the fluorogenic substrate, Ac-DEVD-AFC. Relative caspase-3 activity is the ratio of treated cells to untreated cells. Means \pm SD of 3 separate experiments are shown.
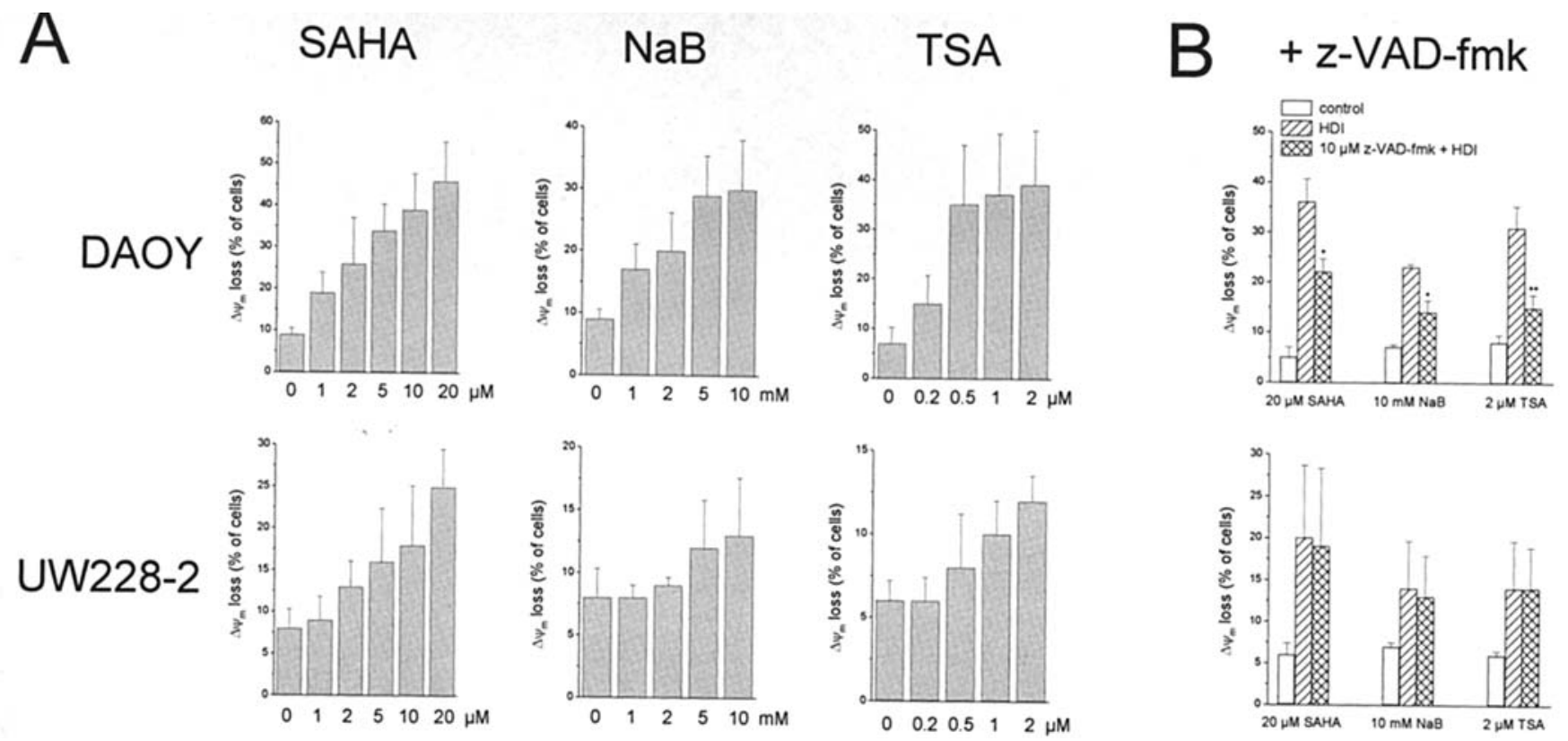

Figure 4. HDIs induce $\Delta \Psi_{\mathrm{m}}$ dissipation. (A) DAOY and UW228-2 cells were incubated with SAHA, NaB, or TSA for 24 h. (B) z-VAD-fmk was applied $1 \mathrm{~h}$ before treatment with HDIs, cells were then incubated for $24 \mathrm{~h} . \Delta \Psi_{\mathrm{m}}$ was assessed by cytofluorometric analysis of DiOC 6 ( 3$)$ staining. Means \pm SD of 3 separate experiments are shown $\left({ }^{*} \mathrm{p}<0.05,{ }^{* *} \mathrm{p}<0.005\right)$.

Caspase-9. Typically, the permeabilization of mitochondria is accompanied by the release of cytochrome $c$ into the cytosol concomitant with the activation of caspase-9. We thus tested whether HDIs could stimulate caspase- 9 activity in DAOY and UW228-2 cells. As demonstrated in Fig. 5, a 24-h exposure to SAHA, NaB, or TSA resulted in a concentrationdependent activation of caspase- 9 in both cell lines: we detected an up to 3- and 4.5-fold increase in caspase-9 activity in DAOY and UW228-2 cells, respectively.

HDIs sensitize DAOY cells to ionizing radiation. Based on established action mechanisms of HDIs (4), we hypothesized that HDIs might sensitize cells to IR. Four hours after treatment with HDIs, DAOY cells were exposed to single doses of IR, 
SAHA
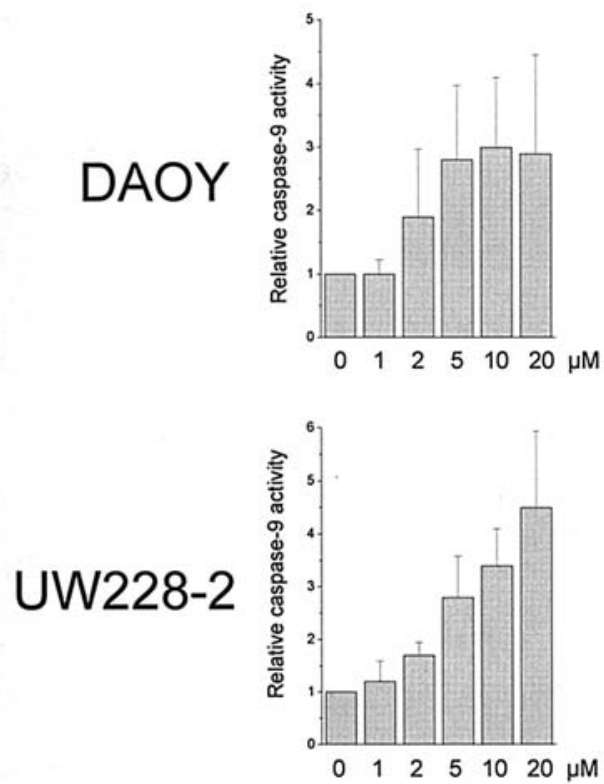

$\mathrm{NaB}$
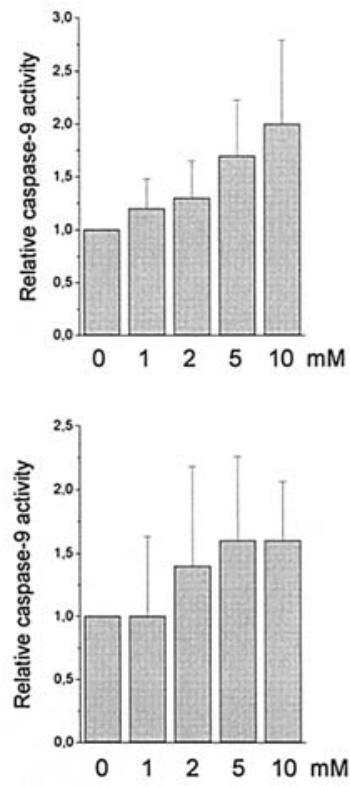

TSA
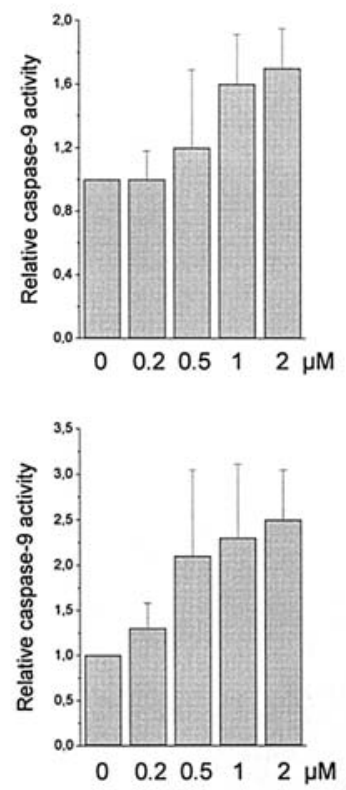

Figure 5. HDIs induce caspase-9 activity. DAOY and UW228-2 cells were incubated with SAHA, NaB, or TSA for 24 h. Caspase-9 activity was measured using the fluorogenic substrate, Ac-LEHD-AFC. Relative caspase-9 activity is the ratio of treated cells to untreated cells. Means \pm SD of 3 separate experiments are shown.

A

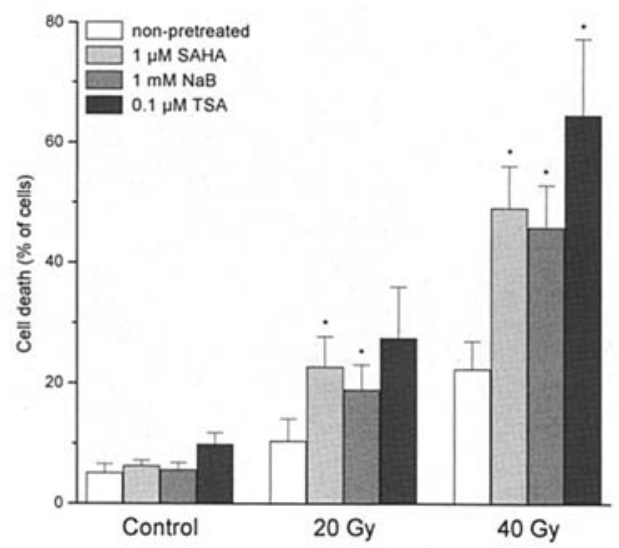

B

DAOY

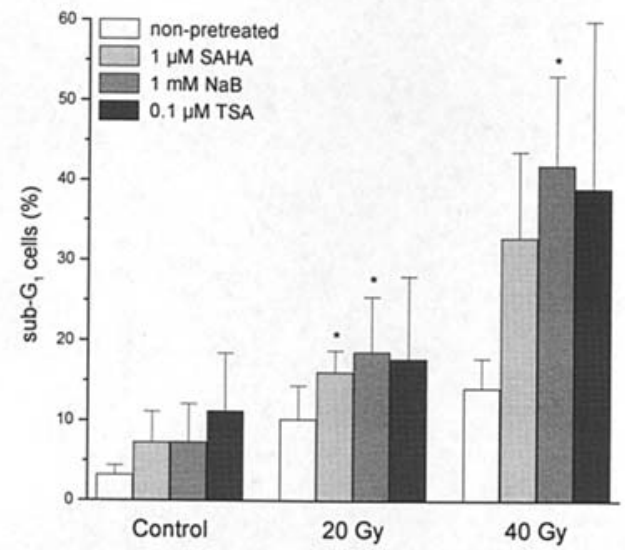

Figure 6. HDIs induce radiosensitization. DAOY cells were irradiated $4 \mathrm{~h}$ after treatment with HDIs and cultured for a further $24 \mathrm{~h}$. (A) Cell death was determined by cytofluorometric analysis of PI uptake. (B) DNA fragmentation was determined by cytofluorometric cell cycle analysis. Means \pm SD of 4 (PI uptake) or 3 (DNA fragmentation) experiments are shown $\left({ }^{*} \mathrm{p}<0.05\right)$.

and PI uptake was determined after a further 24-h incubation. As shown in Fig. 6A, the modest doses of HDIs ( $1 \mu \mathrm{M}$ SAHA, $1 \mathrm{mM} \mathrm{NaB}$, or $0.1 \mu \mathrm{M}$ TSA) applied in these experiments had little effect on cell viability. Likewise, cells displayed only moderate responsiveness to IR alone: doses of 20 or $40 \mathrm{~Gy}$ elicited 10.5 and $22 \%$ cell death, respectively. However, combined treatment with HDIs and IR resulted in supraadditive cytotoxicity with $19-27.5 \%$ cell killing at 20 Gy and $46-65 \%$ cell killing at $40 \mathrm{~Gy}$. This potentiation of cell death with a combined treatment of HDIs and IR was further confirmed using cell-cycle analysis to assess DNA fragment- ation. As illustrated in Fig. 6B, treatment with IR alone caused only a weak increase in sub- $\mathrm{G}_{1}$ cells $(10 \%$ at $20 \mathrm{~Gy}$ and $14 \%$ at $40 \mathrm{~Gy})$. In contrast, in cells pretreated with SAHA, NaB, or TSA for $4 \mathrm{~h}$, IR at 20 or 40 Gy provoked DNA fragmentation in 16-19 and 33-42\%, respectively, of cells.

SAHA sensitizes DAOY cells to etoposide, but not to vincristine. We also evaluated whether SAHA could increase the efficiency of drugs used for the management of medulloblastoma, such as etoposide and vincristine. DAOY cells were pretreated 


\section{DAOY}

\section{Etoposide}

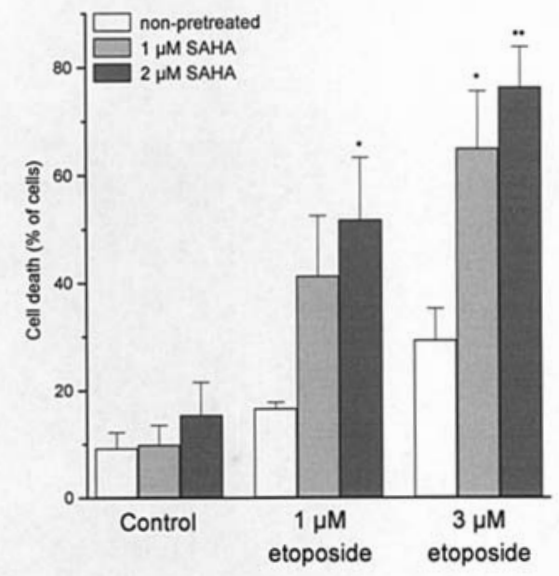

\section{Vincristine}

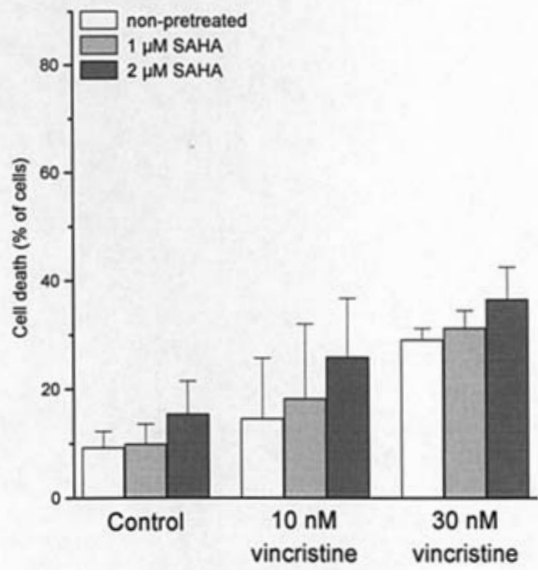

Figure 7. HDIs induce sensitization to etoposide, but not to vincistine. Four hours after treatment with SAHA, DAOY cells were exposed to etoposide or vincristine for further $24 \mathrm{~h}$. Cell death was determined by cytofluorometric analysis of PI uptake. Means \pm SD of each 3 experiments are shown $\left({ }^{*} \mathrm{p}<0.05,{ }^{* *} \mathrm{p}<0.005\right)$

with 1 or $2 \mu \mathrm{M}$ SAHA for $4 \mathrm{~h}$, and cultured with the cytostatics for a further $24 \mathrm{~h}$. At the highest doses applied (3 $\mu \mathrm{M}$ etoposide, $30 \mathrm{nM}$ vincristine), the cytostatics alone evoked cell death in $29 \%$ of cells. Pretreatment with SAHA potently increased etoposide killing efficiency, resulting in up to $76 \%$ non-viable cells (Fig. 7). In contrast, the combined treatment of SAHA and vincristine led to a mere additive effect. This discrepancy of the impact of SAHA on either etoposide or vincristine treatment may be attributable to the different modes of action of these cytostatics (see Discussion).

HDIs sensitize medulloblastoma cells to TRAIL. Finally, we investigated whether HDIs would sensitize medulloblastoma cells also to TRAIL-mediated apoptosis. First, we monitored cell death in DAOY and UW228-2 cells by PI uptake. Twentyfour hours after treatment with HDIs, cells were exposed to varying concentrations of TRAIL for another $24 \mathrm{~h}$. As presented in Fig. 8A, non-pretreated cells showed some responsiveness at the highest dose $(100 \mathrm{ng} / \mathrm{ml})$ of TRAIL applied (18 or $10 \%$ cell death in DAOY and UW228- 2 cells, respectively). In cells pretreated with $2 \mu \mathrm{M}$ SAHA, $2 \mathrm{mM}$ $\mathrm{NaB}$, or $0.2 \mu \mathrm{M}$ TSA, however, TRAIL evoked a pronounced cytotoxic effect, with up to $94 \%$ cell killing in DAOY cells and up to $60 \%$ cell killing in UW228-2 cells. Second, cells were assessed for DNA fragmentation by cell-cycle analysis. Treatment with TRAIL alone for $24 \mathrm{~h}$ resulted in DNA fragmentation in a maximum of 19 or $17 \%$ in DAOY and UW228-2 cells, respectively (Fig. 8B). When the same experiment was carried out after pretreatment with HDIs for $24 \mathrm{~h}$, a highly significant increase of apoptotic cells was observed, with sub- $\mathrm{G}_{1}$ fractions amounting to up to $78 \%$ in DAOY cells and up to 52\% in UW228-2 cells. Third, we determined the effect of HDIs on TRAIL-induced caspase- 3 activity. In DAOY cells afore treated with HDIs for $24 \mathrm{~h}$, $100 \mathrm{ng} / \mathrm{ml}$ TRAIL activated caspase- 3 by at least 22 -fold whereas, in non-pretreated cells, only an 11.5-fold increase in caspase-3 activity was observed (Fig. 8C). In UW228-2 cells, treatment with $100 \mathrm{ng} / \mathrm{ml}$ TRAIL resulted in a 7-fold caspase-3 activation and an at least 14.5-fold activation in cells pretreated with HDIs for $24 \mathrm{~h}$.

TRAIL-mediated apoptosis has been shown to involve $\Delta \Psi_{\mathrm{m}}$ dissipation (29). We thus analyzed whether HDIs and TRAIL would interact at the mitochondrial level to induce apoptosis. DAOY cells were cultured with $2 \mu \mathrm{M}$ SAHA for $24 \mathrm{~h}$, and exposed to $100 \mathrm{ng} / \mathrm{ml}$ TRAIL for a further $24 \mathrm{~h}$. As shown in Fig. 8D, treatment with SAHA or TRAIL alone led to $\Delta \Psi_{\mathrm{m}}$ loss in 25 or $48 \%$ of cells, respectively. After combined treatment of SAHA and TRAIL, decay of $\Delta \Psi_{\mathrm{m}}$ occurred in $92 \%$ of cells. In addition, we asked whether the observed activation of mitochondria could depend on the activation of caspase-8, an initiator caspase employed by active death receptors (30). TRAIL-triggered decline of $\Delta \Psi_{\mathrm{m}}$ could be prevented by the caspase- 8 inhibitor, z-IETD-fmk. In contrast, z-IETD-fmk had no effect on SAHA-induced $\Delta \Psi_{\mathrm{m}}$ dissipation. These results show that active caspase- 8 is required for TRAILinduced, but not for SAHA-induced, apoptosis via the mitochondrial pathway.

HDI treatment leads to histone acetylation in medulloblastoma cells. The effect of SAHA, NaB and TSA on histone acetylation was examined in order to confirm that HDIs effectively inhibit the enzymatic activity of histone deacetylases. DAOY and UW228-2 cells were incubated with the indicated concentrations of HDIs for $24 \mathrm{~h}$, and the acetylation status of histone $\mathrm{H} 3$ was analyzed by Western blotting using an acetylated H3-specific antibody. As presented in Fig. 9, treatment with all three HDIs induced pronounced histone H3 hyperacetylation in both cell lines.

\section{Discussion}

HDIs induce growth arrest, activate differentiation, and/or elicit apoptosis in many epithelial and hematological malignancies 
A

DAOY

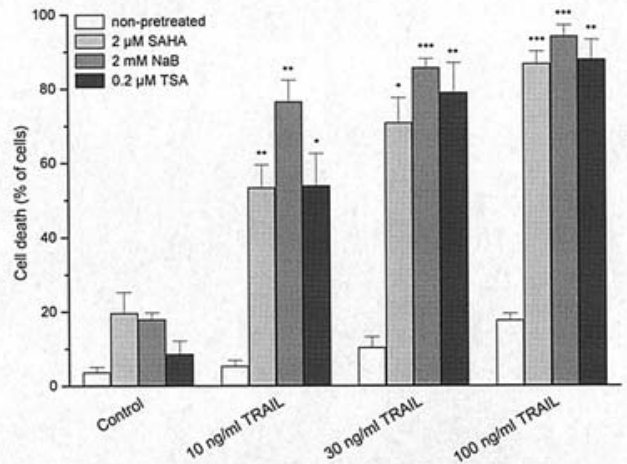

UW228-2

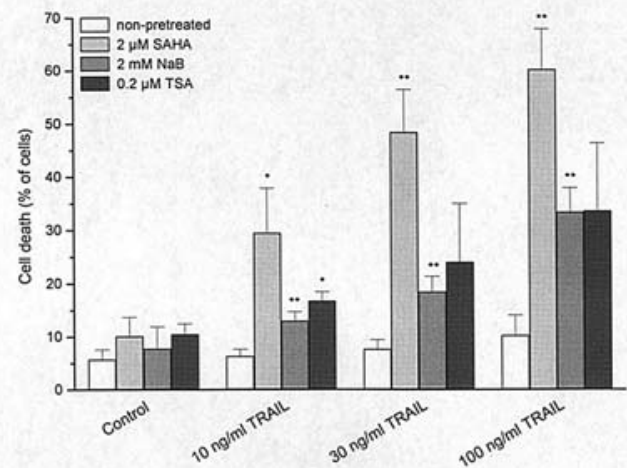

C

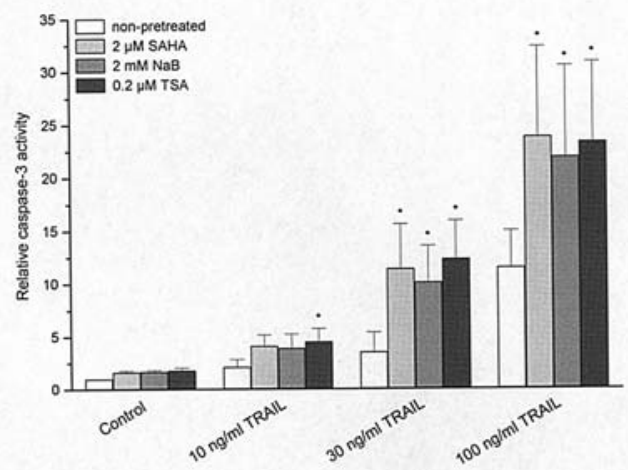

UW228-2

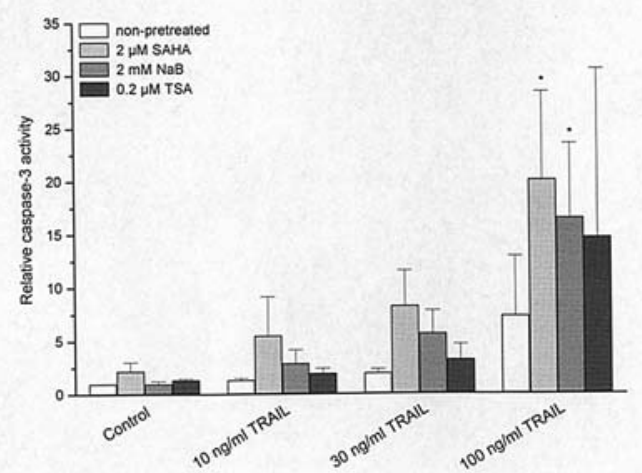

B

DAOY

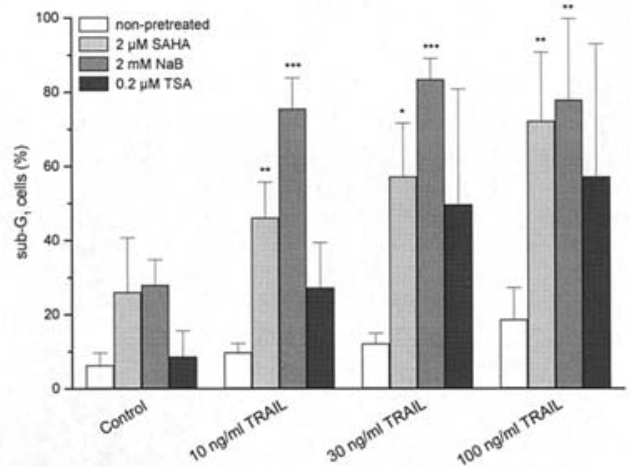

UW228-2

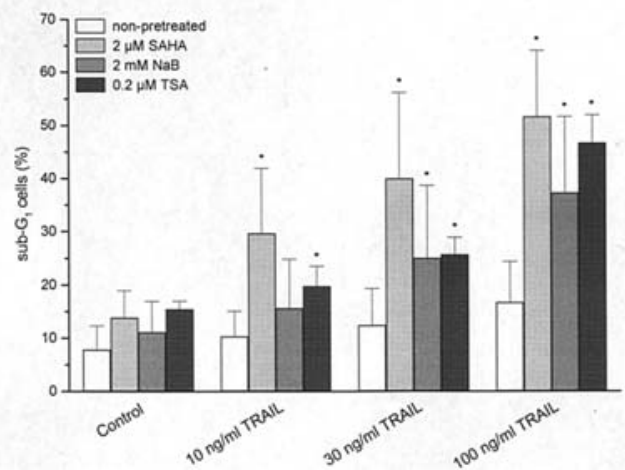

D
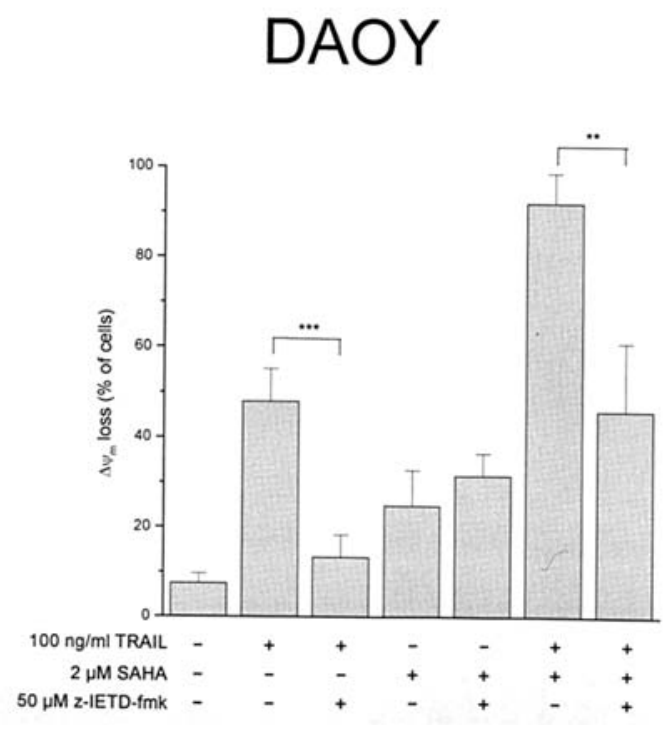

Figure 8. HDIs induce sensitization to TRAIL. Twenty-four hours after administration of HDIs, DAOY and UW228-2 cells were treated with TRAIL. (A) Twenty-four hours after treatment with TRAIL, cell death was determined by cytofluorometric analysis of PI uptake. (B) Twenty-four hours after treatment with TRAIL, DNA fragmentation was determined by cytofluorometric cell cycle analysis. (C) Two (DAOY) or 3 (UW228-2) h after treatment with TRAIL, caspase- 3 activity was measured using the fluorogenic substrate, Ac-DEVD-AFC. Relative caspase-3 activity is the ratio of treated cells to untreated cells. (D) DAOY cells were treated with z-IETD-fmk $1 \mathrm{~h}$ before administration of TRAIL, cells were then incubated for $24 \mathrm{~h} . \Delta \Psi_{\mathrm{m}}$ was assessed by cytofluorometric analysis of $\operatorname{DiOC}_{6}(3)$ staining. Means \pm SD of 3-4 separate experiments are shown $\left({ }^{*} \mathrm{p}<0.05\right.$, $\left.{ }^{* *} \mathrm{p}<0.005,{ }^{* * *} \mathrm{p}<0.001\right)$. 
DAOY

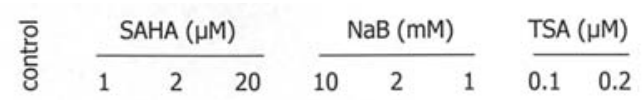

Acetylated $\mathrm{H} 3$

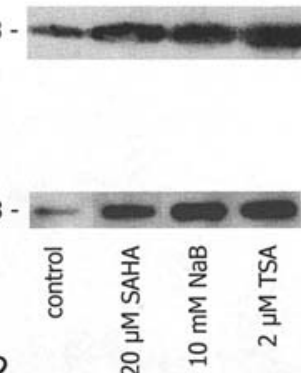

UW228-2

\begin{tabular}{|c|c|c|c|c|}
\hline ?-2ר?৪ & $\begin{array}{l}\overline{ } \\
\text { 동 }\end{array}$ & $\begin{array}{l}\text { 営 } \\
\text { ஸे } \\
\sum_{3}\end{array}$ & 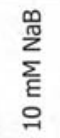 & $\begin{array}{l}\underset{5}{\leftarrow} \\
\underset{\Sigma}{N}\end{array}$ \\
\hline
\end{tabular}

Figure 9. HDIs increase acetylation of histone H3. DAOY and UW228-2 cells were treated for $24 \mathrm{~h}$ with the indicated concentrations of SAHA, NaB or TSA. Total protein $(30 \mu \mathrm{g})$ was separated by a $10 \%$ polyacrylamide gel. Western blot analyses were performed with antibodies against acetylated histone H3. GAPDH was used as a loading control.

(31). However, the effects of these compounds on medulloblastoma have not been fully investigated. Recent studies have shown that the benzamide derivative, MS-275, inhibits DNA synthesis in DAOY and D283-Med medulloblastoma cells (23), and that the carboxylic acids, phenylbutyrate and phenylacetate, induce differentiation and inhibit proliferation in these cell lines in vitro and in vivo (24). Here, we demonstrate that the HDIs SAHA, NaB, and TSA were effective in inducing cell death in DAOY and UW228-2 medulloblastoma cells. This is evidenced by a number of different read-outs. As judged by PI uptake, we observed that all three HDIs acted very similarly in initiating death in both the cell lines; however, DAOY cells were more sensitive to HDIs, which might be related to their higher growth rate. Several lines of evidence indicate that HDIs triggered cell death in DAOY and UW228-2 through the induction of apoptosis. Apoptosis is initiated in response to a number of stimuli, including antineoplastic agents, and is usually mediated through the activation of caspases, eventually resulting in typical morphological changes such as DNA fragmentation (30). We found that exposure to HDIs led to the accumulation of sub- $\mathrm{G}_{1}$ cells, a finding that is consistent with DNA fragmentation and apoptosis. We also found that HDIs potently activated capase-3, another feature characteristic of apoptosis. Apoptosis can proceed via two pathways, the death receptor (extrinsic) and the mitochondrial (intrinsic) pathway; typically, chemotherapeutic drugs harness the mitochondrial pathway of apoptosis. SAHA, NaB, and TSA induced loss of $\Delta \Psi_{\mathrm{m}}$, which was paralleled by the activation of caspase-9, demonstrating the functionality of the intrinsic pathway in HDI-triggered apoptosis in medulloblastoma cells.

The importance of caspases for HDI-induced apoptosis is a controversial issue. For example, SAHA has been reported to elicit cell death in leukemia and colon carcinoma cells independent of the activation of caspase- 8 or $-3(26,32,33)$. On the other hand, several reports point to a critical role of the caspase system for HDI-mediated apoptosis (28,34-36). Hence, the significance of caspase activation in the apoptotic pathway induced by HDIs is uncertain. However, chemoresistance in various malignant tumors has been related to defects in the caspase system $(37,38)$. Thus, the definition of the role of caspases in HDI-induced apoptosis may have implications for developing strategies especially for the treatment of chemoresistant cancers. We demonstrate that the three HDIs investigated were strong inducers of caspase-3 and -9 activity in DAOY and UW228-2 cells. However, the activation of a caspase does not necessarily imply its requirement for the apoptotic process. Consequently, additional analyses were performed to dissect whether activated caspases are indispensable components in the HDI-triggered apoptotic machinery. Experiments using the polycaspase inhibitor, zVAD-fmk, revealed that activated caspases were indeed required for HDI-provoked cell death in DAOY cells, as judged by measuring PI uptake, by quantifying DNA fragmentation, and by determining $\Delta \Psi_{\mathrm{m}}$. In contrast, HDI-induced cell death was only slightly affected by z-VAD-fmk in UW228-2 cells, indicating that the activity of caspases which are blocked by $\mathrm{z}$-VAD-fmk is less critical for the cytotoxic activity of HDIs in UW228-2 cells. Hence, the contradictory findings regarding the role of caspases for HDI-triggered apoptosis might be explicable by the different cell lines employed in different studies.

As an accessory finding of the cell-cycle analyses, an HDIinduced $\mathrm{G}_{2} / \mathrm{M}$ arrest was observed when cells were protected from apoptosis by z-VAD-fmk, consistent with previous reports $(39,40)$. Inhibition of caspases did not only prevent HDI-induced apoptosis in DAOY cells but significantly and systematically increased the percentage of $\mathrm{G}_{2} / \mathrm{M}$ cells (on expense of $G_{1}$ cells) even above the levels of $G_{2} / M$ cells in the controls. The mechanism by which HDIs arrest cells in $\mathrm{G}_{2} / \mathrm{M}$ has not yet been clearly defined (41). HDI-induced $\mathrm{G}_{2} / \mathrm{M}$ arrest has been found to associate with the reduced expression of cyclins $A$ and $B$ as well as CDK1, key components for $G_{2} / M$ transition, and the increased expression of the CDK inhibitors, p21 and p27 $(42,43)$. In addition, it has been reported that HDIs induce a $\mathrm{G}_{2} / \mathrm{M}$ block by activating the p38 MAPK checkpoint (44). In any case, our observation shows that HDIs are still capable of eliciting growth arrest when their apoptosisinducing activity is blocked. Therefore, HDIs might be useful for the treatment of cancers with curtailed apoptotic responsiveness due to defects in the caspase system.

The greatest potential of HDIs may lie in their capability to enhance the antitumor efficiency of other therapeutic regimens, such as IR or chemotherapy. With respect to medulloblastoma, an improvement of the efficacy of IR is especially desirable: although IR is a very efficient treatment for this disease, it is associated with severe neurological toxic side-effects (2). Thus, in order to reduce morbidity with IR, in the USA, the standard craniospinal radiation dose has been lowered from 36 Gy to 23.4 Gy by the introduction of adjuvant chemotherapy (45). Nonetheless, a dose of 23.4 Gy is still associated with neurocognitive sequelae, particularly in children younger than 8 years (46). A further reduction in radiation dose bears the chance of decreasing IR-related morbidity, but also bears the risk of reducing disease control. Our data demonstrate the capacity of HDIs to enhance IRinduced cytotoxicity in DAOY cells. In fact, a dose of 20 Gy after pretreatment with HDIs was as effective in cell killing as a dose of 40 Gy without pretreatment. Similar favorable interactions between HDIs and IR have been described in a few studies. Pretreatment or coadministration of different HDIs has been shown to augment radiosensivity in prostate carcinoma 
$(20,47,48)$, glioma (22), gastrointestinal carcinoma (49), squamous carcinoma (50), and melanoma (51). However, the mechanism responsible for enhanced IR response after inhibition of histone deacetylases has not been clearly defined. One explanation for HDI-mediated radiosensitization lies in HDI impact on chromatin structure: HDIs facilitate decondensation of chromatin; relaxed chromatin has been reported to be generally more sensitive to IR $(52,53)$.

If the looser chromatin structure was responsible for elevated radiosensitivity, an HDI-induced increase in chromatin accessibility might also render cells more sensitive to antineoplastic drugs that target DNA or enzymes acting on the DNA. To address this possibility, we combined SAHA with etoposide, a drug frequently employed in the management of medulloblastoma. Etoposide functions by locking topoisomerase II to the DNA, resulting in irreversible DNA damage during the replication process. Our results demonstrate that pretreatment with SAHA indeed led to a strongly increased killing efficiency of etoposide. We compared this to the combination of SAHA with vincristine, another agent commonly used in medulloblastoma treatment, which does not target the DNA but exerts its cytotoxicity by acting on mitotic spindle microtubules. Our data show that pretreatment with SAHA had no significant effect on vincristine-mediated cell death, indicating that HDIs do not unspecifically increase anticancer drug cytotoxicity irrespective of the drug's mode of action. These observations are in concordance with a recent study which shows that pretreatment with HDIs enhances the cytotoxicity of DNA-targeting agents but not that of the antimetabolite 5-fluorouracil (19).

However, chemotherapy activates the apoptotic machinery only indirectly; more effective outcomes might be accomplished by direct induction of apoptosis. In this respect, TRAIL is a highly promising candidate, as it provokes cell death in the majority of cancer cells without inflicting collateral damage on most normal cells (29). Nevertheless, some cancers fail to respond to TRAIL's cytotoxic effects, suggesting that treatment with TRAIL alone may be insufficient for cancer therapy. In several tumor types, TRAIL activity could be amplified by cotreatment with HDIs. For example, coadministration of HDIs increased the killing efficiency of TRAIL in leukemia cells (54), colon carcinoma cells (55), mesothelioma cells (56), breast cancer cells (57), and lung and prostate cancer cells (58). In this study, we demonstrate that HDIs and TRAIL synergized to induce apoptosis in medulloblastoma cells, as evidenced by measuring PI uptake, quantifying DNA fragmentation, and determining caspase-3 activity. Notably, HDIs and TRAIL also synergistically affected mitochondrial function, indicating that the activities of HDIs and TRAIL converge upstream of mitochondria. TRAIL-triggered decline of $\Delta \Psi_{\mathrm{m}}$ could be abolished by the caspase-8-specific inhibitor, z-IETD-fmk, showing that caspase- 8 is essential for the TRAIL-mediated mitochondrial death pathway in DAOY cells. In contrast, z-IETD-fmk had no effect on SAHAinduced $\Delta \Psi_{\mathrm{m}}$ loss, ruling out the possible involvement of caspase- 8 in SAHA-triggered apoptosis. In leukemia cells, HDIs have been shown to elicit apoptosis via the TRAIL receptor pathway $(59,60)$. If this was also the case, however, in medulloblastoma cells, the inhibition of caspase- 8 should have resulted in the inhibition of SAHA-induced mitochondrial depolarization. Therefore, the data presented here provide evidence that the activation of the death receptor pathway does not account for HDI-mediated cell death in medulloblastoma cells.

In conclusion, our results suggest that HDIs may be useful for the treatment of medulloblastoma as monotherapy and particularly when given in combination with IR, appropriate cytostatics, or TRAIL. Given the importance of IR for the treatment of medulloblastoma, it now will be of special interest to disclose the mechanisms that account for the sensitization of medulloblastoma cells to IR by HDIs on a molecular level, as such findings may lead to the development of improved treatment tools for medulloblastoma.

\section{Acknowledgements}

We thank J. Gänge, U. Glawe, and A. Plath for their excellent technical assistance. This work was supported by a grant from the Deutsche Krebshilfe.

\section{References}

1. Packer RJ, Goldwein J, Nicholson HS, Vezina LG, Allen JC, Ris MD, Muraszko K, Rorke LB, Wara WM, Cohen BH and Boyett JM: Treatment of children with medulloblastomas with reduced-dose craniospinal radiation therapy and adjuvant chemotherapy: A Children's Cancer Group Study. J Clin Oncol 17: 2127-2136, 1999.

2. Mulhern RK, Merchant TE, Gajjar A, Reddick WE and Kun LE: Late neurocognitive sequelae in survivors of brain tumours in childhood. Lancet Oncol 5: 399-408, 2004.

3. Marks P, Rifkind RA, Richon VM, Breslow R, Miller T and Kelly WK: Histone deacetylases and cancer: causes and therapies. Nat Rev Cancer 1: 194-202, 2001.

4. Johnstone RW: Histone-deacetylase inhibitors: novel drugs for the treatment of cancer. Nat Rev Drug Discov 1: 287-299, 2002.

5. Blagosklonny MV, Robey R, Sackett DL, Du L, Traganos F, Darzynkiewicz Z, Fojo T and Bates SE: Histone deacetylase inhibitors all induce p21 but differentially cause tubulin acetylation, mitotic arrest, and cytotoxicity. Mol Cancer Ther 1: 937-941, 2002.

6. Glick RD, Swendeman SL, Coffey DC, Rifkind RA, Marks PA, Richon VM and La Quaglia MP: Hybrid polar histone deacetylase inhibitor induces apoptosis and CD95/CD95 ligand expression in human neuroblastoma. Cancer Res 59: 4392-4399, 1999.

7. Schmidt K, Gust R and Jung M: Inhibitors of histone deacetylase suppress the growth of MCF-7 breast cancer cells. Arch Pharm (Weinheim) 332: 353-357, 1999.

8. Butler LM, Agus DB, Scher HI, Higgins B, Rose A, CordonCardo C, Thaler HT, Rifkind RA, Marks PA and Richon VM: Suberoylanilide hydroxamic acid, an inhibitor of histone deacetylase, suppresses the growth of prostate cancer cells in vitro and in vivo. Cancer Res 60: 5165-5170, 2000.

9. Park WH, Jung CW, Park JO, Kim K, Kim WS, Im YH, Lee MH, Kang WK and Park K: Trichostatin inhibits the growth of ACHN renal cell carcinoma cells via cell cycle arrest in association with p27, or apoptosis. Int J Oncol 22: 1129-1134, 2003.

10. Saito A, Yamashita T, Mariko Y, Nosaka Y, Tsuchiya K, Ando T, Suzuki T, Tsuruo T and Nakanishi O: A synthetic inhibitor of histone deacetylase, MS-27-275, with marked in vivo antitumor activity against human tumors. Proc Natl Acad Sci USA 96: 4592-4597, 1999.

11. He LZ, Tolentino T, Grayson P, Zhong S, Warrell RP Jr, Rifkind RA, Marks PA, Richon VM and Pandolfi PP: Histone deacetylase inhibitors induce remission in transgenic models of therapy-resistant acute promyelocytic leukemia. J Clin Invest 108: 1321-1330, 2001.

12. Gilbert J, Baker SD, Bowling MK, Grochow L, Figg WD, Zabelina Y, Donehower RC and Carducci MA: A phase I dose escalation and bioavailability study of oral sodium phenylbutyrate in patients with refractory solid tumor malignancies. Clin Cancer Res 7: 2292-2300, 2001. 
13. Sandor V, Bakke S, Robey RW, Kang MH, Blagosklonny MV, Bender J, Brooks R, Piekarz RL, Tucker E, Figg WD, Chan KK, Goldspiel B, Fojo AT, Balcerzak SP and Bates SE: Phase I trial of the histone deacetylase inhibitor, depsipeptide (FR901228, NSC 630176), in patients with refractory neoplasms. Clin Cancer Res 8: 718-728, 2002.

14. Gore SD, Weng LJ, Figg WD, Zhai S, Donehower RC, Dover G, Grever MR, Griffin C, Grochow LB, Hawkins A, Burks K, Zabelena Y and Miller CB: Impact of prolonged infusions of the putative differentiating agent sodium phenylbutyrate on myelodysplastic syndromes and acute myeloid leukemia. Clin Cancer Res 8: 963-970, 2002.

15. Kelly WK, Richon VM, O'Connor O, Curley T, MacGregorCurtelli B, Tong W, Klang M, Schwartz L, Richardson S, Rosa E, Drobnjak M, Cordon-Cordo C, Chiao JH, Rifkind R, Marks PA and Scher H: Phase I clinical trial of histone deacetylase inhibitor: suberoylanilide hydroxamic acid administered intravenously. Clin Cancer Res 9: 3578-3588, 2003.

16. Ryan QC, Headlee D, Acharya M, Sparreboom A, Trepel JB, Ye J, Figg WD, Hwang K, Chung EJ, Murgo A, Melillo G, Elsayed Y, Monga M, Kalnitskiy M, Zwiebel J and Sausville EA: Phase I and pharmacokinetic study of MS-275, a histone deacetylase inhibitor, in patients with advanced and refractory solid tumors or lymphoma. J Clin Oncol 23: 3912-3922, 2005.

17. Kelly WK, O'Connor OA, Krug LM, Chiao JH, Heaney M, Curley T, MacGregore-Cortelli B, Tong W, Secrist JP, Schwartz L, Richardson S, Chu E, Olgac S, Marks PA, Scher H and Richon VM: Phase I study of an oral histone deacetylase inhibitor, suberoylanilide hydroxamic acid, in patients with advanced cancer. J Clin Oncol 23: 3923-3931, 2005.

18. Sawa H, Murakami H, Ohshima Y, Sugino T, Nakajyo T, Kisanuki T, Tamura Y, Satone A, Ide W, Hashimoto I and Kamada H: Histone deacetylase inhibitors such as sodium butyrate and trichostatin A induce apoptosis through an increase of the bcl-2-related protein Bad. Brain Tumor Pathol 18: 109-114, 2001.

19. Kim MS, Blake M, Baek JH, Kohlhagen G, Pommier Y and Carrier F: Inhibition of histone deacetylase increases cytotoxicity to anticancer drugs targeting DNA. Cancer Res 63: 7291-7300, 2003.

20. Camphausen K, Burgan W, Cerra M, Oswald KA, Trepel JB, Lee MJ and Tofilon PJ: Enhanced radiation-induced cell killing and prolongation of gammaH2 $\mathrm{AX}$ foci expression by the histone deacetylase inhibitor MS-275. Cancer Res 64: 316-321, 2004.

21. Appelskog IB, Ammerpohl O, Svechnikova IG, Lui WO, Almqvist PM and Ekstrom TJ: Histone deacetylase inhibitor 4-phenylbutyrate suppresses GAPDH mRNA expression in glioma cells. Int J Oncol 24: 1419-1425, 2004.

22. Camphausen K, Cerna D, Scott T, Sproull M, Burgan WE, Cerra MA, Fine $\mathrm{H}$ and Tofilon PJ: Enhancement of in vitro and in vivo tumor cell radiosensitivity by valproic acid. Int J Cancer 114: 380-386, 2005.

23. Jaboin J, Wild J, Hamidi H, Khanna C, Kim CJ, Robey R, Bates SE and Thiele CJ: MS-27-275, an inhibitor of histone deacetylase, has marked in vitro and in vivo antitumor activity against pediatric solid tumors. Cancer Res 62: 6108-6115, 2002.

24. Li XN, Parikh S, Shu Q, Jung HL, Chow CW, Perlaky L, Leung HC, Su J, Blaney S and Lau CC: Phenylbutyrate and phenylacetate induce differentiation and inhibit proliferation of human medulloblastoma cells. Clin Cancer Res 10: 1150-1159, 2004.

25. Fischer U, Janicke RU and Schulze-Osthoff K: Many cuts to ruin: a comprehensive update of caspase substrates. Cell Death Differ 10: 76-100, 2003.

26. Peart MJ, Tainton KM, Ruefli AA, Dear AE, Sedelies KA, O'Reilly LA, Waterhouse NJ, Trapani JA and Johnstone RW: Novel mechanisms of apoptosis induced by histone deacetylase inhibitors. Cancer Res 63: 4460-4471, 2003.

27. Zhang XD, Gillespie SK, Borrow JM and Hersey P: The histone deacetylase inhibitor suberic bishydroxamate regulates the expression of multiple apoptotic mediators and induces mitochondria-dependent apoptosis of melanoma cells. Mol Cancer Ther 3: 425-435, 2004

28. Doi S, Soda H, Oka M, Tsurutani J, Kitazaki T, Nakamura Y, Fukuda M, Yamada Y, Kamihira S and Kohno S: The histone deacetylase inhibitor FR901228 induces caspase-dependent apoptosis via the mitochondrial pathway in small cell lung cancer cells. Mol Cancer Ther 3: 1397-1402, 2004.

29. Le Blanc HN and Ashkenazi A: Apo2L/TRAIL and its death and decoy receptors. Cell Death Differ 10: 66-75, 2003.
30. Johnstone RW, Ruefli AA and Lowe SW: Apoptosis: a link between cancer genetics and chemotherapy. Cell 108: 153-164, 2002.

31. Mei S, Hoh AD and Mahlknecht U: Role of histone deacetylase inhibitors in the treatment of cancer (Review). Int J Oncol 25: 1509-1519, 2004

32. Ruefli AA, Ausserlechner MJ, Bernhard D, Sutton VR, Tainton KM, Kofler R, Smyth MJ and Johnstone RW: The histone deacetylase inhibitor and chemotherapeutic agent suberoylanilide hydroxamic acid (SAHA) induces a celldeath pathway characterized by cleavage of Bid and production of reactive oxygen species. Proc Natl Acad Sci USA 98: 10833-10838, 2001

33. Mitsiades N, Mitsiades CS, Richardson PG, McMullan C, Poulaki V, Fanourakis G, Schlossman R, Chauhan D, Munshi NC, Hideshima T, Richon VM, Marks PA and Anderson KC: Molecular sequelae of histone deacetylase inhibition in human malignant B cells. Blood 101: 4055-4062, 2003.

34. Henderson C, Mizzau M, Paroni G, Maestro R, Schneider C and Brancolini C: Role of caspases, Bid, and p53 in the apoptotic response triggered by histone deacetylase inhibitors trichostatin-A (TSA) and suberoylanilide hydroxamic acid (SAHA). J Biol Chem 278: 12579-12589, 2003.

35. Aron JL, Parthun MR, Marcucci G, Kitada S, Mone AP, Davis ME, Shen T, Murphy T, Wickham J, Kanakry C, Lucas DM, Reed JC, Grever MR and Byrd JC: Depsipeptide (FR901228) induces histone acetylation and inhibition of histone deacetylase in chronic lymphocytic leukemia cells concurrent with activation of caspase 8-mediated apoptosis and downregulation of c-FLIP protein. Blood 102: 652-658, 2003.

36. Sonnemann J, Hartwig M, Plath A, Kumar KS, Muller C and Beck JF: Histone deacetylase inhibitors require caspase activity to induce apoptosis in lung and prostate carcinoma cells. Cancer Lett (In press).

37. Soengas MS, Capodieci P, Polsky D, Mora J, Esteller M, Opitz-Araya X, McCombie R, Herman JG, Gerald WL, Lazebnik YA, Cordon-Cardo $\mathrm{C}$ and Lowe SW: Inactivation of the apoptosis effector Apaf-1 in malignant melanoma. Nature 409: 207-211, 2001

38. Schimmer AD, Pedersen IM, Kitada S, Eksioglu-Demiralp E, Minden MD, Pinto R, Mah K, Andreeff M, Kim Y, Suh WS and Reed JC: Functional blocks in caspase activation pathways are common in leukemia and predict patient response to induction chemotherapy. Cancer Res 63: 1242-1248, 2003.

39. Bernhard D, Ausserlechner MJ, Tonko M, Loffler M, Hartmann BL, Csordas A and Kofler R: Apoptosis induced by the histone deacetylase inhibitor sodium butyrate in human leukemic lymphoblasts. FASEB J 13: 1991-2001, 1999.

40. Piekarz RL, Robey RW, Zhan Z, Kayastha G, Sayah A, Abdeldaim AH, Torrico S and Bates SE: T-cell lymphoma as a model for the use of histone deacetylase inhibitors in cancer therapy: impact of depsipeptide on molecular markers, therapeutic targets, and mechanisms of resistance. Blood 103: 4636-4643, 2004.

41. Qiu L, Burgess A, Fairlie DP, Leonard H, Parsons PG and Gabrielli BG: Histone deacetylase inhibitors trigger a G2 checkpoint in normal cells that is defective in tumor cells. Mol Biol Cell 11: 2069-2083, 2000.

42. Greenberg VL, Williams JM, Cogswell JP, Mendenhall M and Zimmer SG: Histone deacetylase inhibitors promote apoptosis and differential cell cycle arrest in anaplastic thyroid cancer cells. Thyroid 11: 315-325, 2001.

43. Noh EJ and Lee JS: Functional interplay between modulation of histone deacetylase activity and its regulatory role in G2-M transition. Biochem Biophys Res Commun 310: 267-273, 2003.

44. Mikhailov A, Shinohara M and Rieder CL: Topoisomerase II and histone deacetylase inhibitors delay the G2/M transition by triggering the p38 MAPK checkpoint pathway. J Cell Biol 166: 517-526, 2004.

45. Gilbertson RJ: Medulloblastoma: signalling a change in treatment. Lancet Oncol 5: 209-218, 2004.

46. Ris MD, Packer R, Goldwein J, Jones-Wallace D and Boyett JM: Intellectual outcome after reduced-dose radiation therapy plus adjuvant chemotherapy for medulloblastoma: a Children's Cancer Group study. J Clin Oncol 19: 3470-3476, 2001.

47. Goh M, Chen F, Paulsen MT, Yeager AM, Dyer ES and Ljungman M: Phenylbutyrate attenuates the expression of Bcl-X(L), DNA-PK, caveolin-1, and VEGF in prostate cancer cells. Neoplasia 3: 331-338, 2001. 
48. Chinnaiyan P, Vallabhaneni G, Armstrong E, Huang SM and Harari PM: Modulation of radiation response by histone deacetylase inhibition. Int J Radiat Oncol Biol Phys 62: 223-229, 2005.

49. Zhang Y, Adachi M, Zhao X, Kawamura R and Imai K: Histone deacetylase inhibitors FK228, N-(2-aminophenyl)-4-[N-(pyridin3-yl-methoxycarbonyl)amino- methyl]benzamide and $\mathrm{m}$ carboxycinnamic acid bis-hydroxamide augment radiationinduced cell death in gastrointestinal adenocarcinoma cells. Int J Cancer 110: 301-308, 2004.

50. Zhang Y, Jung M, Dritschilo A and Jung M: Enhancement of radiation sensitivity of human squamous carcinoma cells by histone deacetylase inhibitors. Radiat Res 161: 667-674, 2004.

51. Munshi A, Kurland JF, Nishikawa T, Tanaka T, Hobbs ML, Tucker SL, Ismail S, Stevens C and Meyn RE: Histone deacetylase inhibitors radiosensitize human melanoma cells by suppressing DNA repair activity. Clin Cancer Res 11: 4912-4922, 2005.

52. Nackerdien Z, Michie J and Bohm L: Chromatin decondensed by acetylation shows an elevated radiation response. Radiat Res 117: 234-244, 1989.

53. Ljungman M: The influence of chromatin structure on the frequency of radiation-induced DNA strand breaks: a study using nuclear and nucleoid monolayers. Radiat Res 126: 58-64, 1991.

54. Rosato RR, Almenara JA, Dai Y and Grant S: Simultaneous activation of the intrinsic and extrinsic pathways by histone deacetylase (HDAC) inhibitors and tumor necrosis factor-related apoptosis-inducing ligand (TRAIL) synergistically induces mitochondrial damage and apoptosis in human leukemia cells. Mol Cancer Ther 2: 1273-1284, 2003.
55. Inoue H, Shiraki K, Ohmori S, Sakai T, Deguchi M, Yamanaka T, Okano $\mathrm{H}$ and Nakano T: Histone deacetylase inhibitors sensitize human colonic adenocarcinoma cell lines to TNF-related apoptosis inducing ligand-mediated apoptosis. Int J Mol Med 9: 521-525, 2002.

56. Neuzil J, Swettenham E and Gellert N: Sensitization of mesothelioma to TRAIL apoptosis by inhibition of histone deacetylase: role of $\mathrm{Bcl}-\mathrm{x}(\mathrm{L})$ down-regulation. Biochem Biophys Res Commun 314: 186-191, 2004.

57. Chopin V, Slomianny C, Hondermarck H and Le BX: Synergistic induction of apoptosis in breast cancer cells by co-treatment with butyrate and TNF-alpha, TRAIL, or anti-Fas agonist antibody involves enhancement of death receptors' signaling and requires P21(waf1). Exp Cell Res 298: 560-573, 2004.

58. Sonnemann J, Gange J, Kumar KS, Muller C, Bader P and Beck JF: Histone deacetylase inhibitors interact synergistically with tumor necrosis factor-related apoptosis-inducing ligand (TRAIL) to induce apoptosis in carcinoma cell lines. Invest New Drugs 23: 99-109, 2005.

59. Insinga A, Monestiroli S, Ronzoni S, Gelmetti V, Marchesi F, Viale A, Altucci L, Nervi C, Minucci S and Pelicci PG: Inhibitors of histone deacetylases induce tumor-selective apoptosis through activation of the death receptor pathway. Nat Med 11: 71-76, 2005

60. Nebbioso A, Clarke N, Voltz E, Germain E, Ambrosino C, Bontempo P, Alvarez R, Schiavone EM, Ferrara F, Bresciani F, Weisz A, De Lera AR, Gronemeyer H and Altucci L: Tumorselective action of HDAC inhibitors involves TRAIL induction in acute myeloid leukemia cells. Nat Med 11: 77-84, 2005. 